\title{
Anti-fungal substances of Bacillus subtilis against Ganoderma boninense
}

\author{
Sinpakone Singhalath* and I Nyoman Pugeg Aryantha
}

Microbial Biotechnology Research Group, School of Life Sciences and Technology, Institut Teknologi Bandung (ITB), JI Ganesha 10 Bandung 40132 Indonesia.

Email: sinpakonesinghalath@gmail.com

\begin{abstract}
Aims: To determine the optimum culture incubation time for $\beta$-glucanase and chitinase production by Bacillus subtilis as well as optimum $\mathrm{pH}$ and temperature condition for enzymatic activity against Ganoderma boninense. The suitable solvent (methanol, ethyl acetate or hexane) for the extraction of bacterial metabolites from $B$. subtilis were also determined.

Methodology and results: In vitro antagonistic activity of antifungal metabolites derived from $B$. subtilis to inhibit the growth of $G$. boninense was evaluated based on time of culture incubation, extraction solvent of the metabolites, and enzymatic treatments conditions including $\mathrm{pH}$ and temperature. The results showed that $\beta$-glucanase could be optimally produced (with a specific activity $4.222 \mathrm{U} / \mathrm{mg}$-protein) after $28 \mathrm{~h}$ of incubation. The optimum $\mathrm{pH}$ and temperature for the activity of $\beta$-glucanase were 7.5 and $45{ }^{\circ} \mathrm{C}$ respectively when $1 \%$ laminarin used as the substrate. B. subtilis showed optimum chitinase activity $(0.0514 \mathrm{U} / \mathrm{mL})$ after $8 \mathrm{~h}$ of incubation. Optimum $\mathrm{pH}$ and temperature of chitinase were at $\mathrm{pH}$ 6.0 and $40{ }^{\circ} \mathrm{C}$, respectively using $1 \%$ colloidal chitin as the substrate. $\beta$-glucanase crude enzyme showed strongest antifungal activities against the mycelial growth of $G$. boninense better than crude enzyme of chitinase with an inhibition rate of $47.75 \%$ at 5 days of incubation. Furthermore, cultivation of $B$. subtilis over $48 \mathrm{~h}$ produced antifungal metabolites which could inhibit the growth of $G$. boninense the most. The best solvent to extract metabolite from $B$. subtilis was identified as ethyl acetate that rendered an inhibition value of $38.91 \%$.

Conclusion, significance, and impact of study: Bacillus subtilis could be a potential biological control agent against G. boninense.
\end{abstract}

Keywords: Bacillus subtilis, Ganoderma boninense, antifungal, $\beta$-glucanase, chitinase

\section{INTRODUCTION}

Ganoderma boninense is a fungal pathogen in oil palm plantations that causes basal stem rot (BSR) disease which is challenging to be eradicated (Hushiarian et al., 2013). Biological disease control has been used to prevent, mitigate or particularly control plant diseases (Pal and Gardener, 2006). Bacillus spp. have shown their ability for controlling a wide variety of fungal infections, operating as an antagonist towards fungal plant pathogens through their production of a several antifungal and antibacterial metabolites such as zwittermicin A, kanosamine and lipopeptides from iturin, surfactin and fenzycin families (Kumar et al., 2009) and hydrolytic enzyme that degrade fungal structurepolymers (e.g. $\beta$ glucanase, chitinase) (Chang et al., 2007).

Many studies have reported the potential of Bacillus subtilis as a biological control agent against fungal pathogens (Arras, 1993; Arras and Dhalewin, 1994; Islam et al., 2012; Mardanova et al., 2017). A strain of B. subtilis was found to produce some volatile compounds and could inhibit the soil born plant pathogens such as Rhizoctonia solani and Pythium ultimum (Fiddaman and
Rossall, 1993). In vitro antagonism assay showed that $B$. subtilis PY-1 was effective against Fusarium oxysporum and many other agricultural fungal pathogens which has a great potential as an agent for biological control of many fungal diseases (Gong et al., 2006). Meena et al. (2016) also reported that the production of both Cyclic lipopeptides (CLPs) iturin A, and fengycin which were produced by $B$. subtilis ABS-S14, inhibited the growth of green mold fungi (Penicillium digitatum), whereas surfactin did not affect straight to $P$. digitatum. In another study case, antagonism of $B$. subtilis strain AG1 was tested against vine wood fungal pathogens as well as Phaeoacremonium aleophilum, Phaeomoniella chlamydospora, Verticillium dahliae and Botryosphaeria rhodian. The assay indicated that metabolites of $B$. subtilis strain AG1 against the growth of all pathogens were tested (Alfonzo et al., 2009).

Glucan is a linear polymer of carbohydrates composed of glucose monomers with $\beta-1,3$ and $\beta-1,6$ glucan bonds, whereby these polymers are present in fungal pathogen cell walls after chitin (Budiarti et al., 2004). $\beta$-glucanase is a hydrolytic enzyme which can degrade glucan compound or laminarin as its substrate to 
glucose monomer or saccharide oligomer (Pitson et al., 1993). $\beta$-glucanase and chitinase enzymes producing rhizobacteria could inhibit the growth of fungal pathogens that contain glucan and chitin compounds in their cell wall (Benitez et al., 2004; Cota et al., 2006). Chitin is reputed to be the second most abundant polymer after cellulose. Chitinase is a group of enzymes that can degrade chitin polymer with two stages. Endochitinase (EC 3.2.1.14) degrades the polymer into oligomers then the oligomer is degraded to monomers by exochitinase ( $\beta$-N-acetyl hexosaminidase (EC 3.2.1.52) (Liu et al., 2010).

Chitinase is used as a biocontrol against various types of fungal pathogens, which is expected to reduce the use of synthetic fungicides (de la Vega et al., 2006). Several studies on the ability of Bacillus sp. to produce chitinase that breaks the chitins to produce $\mathrm{N}$-acetylglucosamine in cultured media (Trotta et al., 1973; Karunya et al., 2011; Senol et al., 2014; Cheba et al., 2016). In fact, the enzymes productions and their reactions depend on more factors than temperature, $\mathrm{pH}$ and components of growth media.

\section{MATERIALS AND METHODS}

\section{Sample collection}

Ganoderma boninense and $B$. subtilis strain E-1 16S rRNA gene (JN648100) cultures used in this study were previously isolated from rhizosphere soil of oil palms in Kalimantan, Indonesia in 2012 by Ajidarma (2012). Ganoderma boninense culture was grown on Potato Dextrose Agar (PDA) plates and the fungal culture was used during 3 to 7 days of cultivation at $27 \pm 2{ }^{\circ} \mathrm{C}$. The bacterium $B$. subtilis strains $\mathrm{E}-1$ was grown and maintained on nutrient agar (NA) medium as a stock culture at $27 \pm 2{ }^{\circ} \mathrm{C}$.

\section{Determination of $B$. subtilis growth and $\beta$-glucanase production}

The bacterium $B$. subtilis (2-4 loopful) were prepared into $50 \mathrm{~mL}$ media containing: $\mathrm{K}_{2} \mathrm{HPO}_{4}(0.1 \%)$, Ammonium sulfate $(0.7 \%)$, Triptone $(0.1 \%), \mathrm{NaCl}(0.1 \%)$, $\mathrm{MgSO}_{4} \cdot 7 \mathrm{H}_{2} \mathrm{O}(0.01 \%)$, yeast extract $(0.05 \%)$ supplemented with $1 \%$ laminarin and incubated on shaker incubator at $37^{\circ} \mathrm{C}$ and $170 \mathrm{rpm}$ agitation until the optical density number was adjusted to $1 \times 10^{8}$ spores $/ \mathrm{mL}$. Furthermore, $1 \%$ inoculum of active culture was cultivated into $250 \mathrm{~mL}$ Erlenmeyer flask containing $100 \mathrm{~mL}$ of enzyme production media (mentioned above) supplemented with $1 \%$ laminarin at $\mathrm{pH}$ 7.0. The culture was collected every $4 \mathrm{~h}$ until $48 \mathrm{~h}$ to measure optical density at $580 \mathrm{~nm}$. The culture was then centrifuged at $3500 \times g$ for 30 min at $4{ }^{\circ} \mathrm{C}$ to obtain the crude extract of the $\beta$-glucanase enzyme (Wijaya, 2015). After centrifugation, the supernatant of $\beta$-glucanase was then measured for its activity by the Somogyi-Nelson method (Natsir, 2014) and protein content analysis conducted (Bradford, 1976).
Assay of $\beta$-glucanase activity and protein concentration

$\beta$-glucanase activity was determined by measuring the reducing sugar hydrolysis of laminarin as a substrate (Wijaya, 2015). The crude extract $(250 \mu \mathrm{L})$ was incubated at $37^{\circ} \mathrm{C}$ for 30 min with $1 \%$ laminarin $(250 \mu \mathrm{L})$ in $50 \mathrm{mM}$ pH 5.2 sodium acetate buffer. The result of the enzyme hydrolysis was reacted with the $500 \mu \mathrm{L}$ reagent of Nelson $A$ and Nelson B reagent, it followed by heating in a 100 ${ }^{\circ} \mathrm{C}$ water-bath for $20 \mathrm{~min}$. The reaction was then allowed to cool as well as the room temperature (at $25^{\circ} \mathrm{C}$ ). Addition, $500 \mu \mathrm{L}$ of arsenomolybdate reagent was added, homogenized and waited for $5 \mathrm{~min}$. The absorbance was measured at a wavelength of $\lambda=540 \mathrm{~nm}$. The amount of reducing sugar released was calculated using glucose as standard.

\section{Characteristic of $\beta$-glucanase activity by $\mathrm{pH}$ and temperature}

$\beta$-glucanase production was characterized by a different range of $\mathrm{pH}$ and temperature. The effect of $\mathrm{pH}$ on $\beta$ glucanase activity was determined by measuring the different range of $\mathrm{pH}$ values $(\mathrm{pH} 5.0$ to 8.0 ) using $1 \%$ laminarin as a substrate under standard assay conditions. The buffers used were $50 \mathrm{mM}$ sodium acetic acid buffer (pH 5.0 and 5.5), and $50 \mathrm{mM}$ sodium phosphate buffer (pH 6.0 to 8.0). The optimum temperature was determined by incubating the reaction mixtures at a different temperature from 30 to $55^{\circ} \mathrm{C}$ with $5^{\circ} \mathrm{C}$ intervals, using the previous observation that $\mathrm{pH}$ optimum of activity. The stability of $\beta$-glucanase activity was correlated by incubating the enzyme activity within optimum $\mathrm{pH}$ and temperature for 30 min (Wijaya, 2015).

\section{Determination of $B$. subtilis growth and chitinase production}

The active bacterium $B$. subtilis (1\% inoculum) was cultivated into $250 \mathrm{~mL}$ Erlenmeyer flask containing 100 $\mathrm{mL}$ of nutrient broth enzyme production medium with $1 \%$ colloidal chitin at $\mathrm{pH} 7.0$. Each culture was incubated at $37{ }^{\circ} \mathrm{C}$ at $170 \mathrm{rpm}$ in shaker incubator and collected every $4 \mathrm{~h}$ until $48 \mathrm{~h}$. Addition, their optical density was measured at $600 \mathrm{~nm}$. The culture was then centrifuged at $3,500 \mathrm{rpm}$ for $20 \mathrm{~min}$ at $4{ }^{\circ} \mathrm{C}$ to obtain the crude extract (supernatant) of extracellular chitinase enzyme (Purkan et al., 2016). The crude chitinase was then measured for its activity.

\section{Assay of chitinase activity and protein concentration}

Chitinase activity was carried out according to Purkan et al. (2016). The crude extract of an extracellular enzyme $(400 \mu \mathrm{L})$ was added with $1 \%$ colloidal chitin substrate $(1600 \mu \mathrm{L})$ which was dissolved in $50 \mathrm{mM} \mathrm{pH} \mathrm{7.0.} \mathrm{The}$ homogenized samples were then incubated at $37^{\circ} \mathrm{C}$ for $30 \mathrm{~min}$. Chitinase activity was determined by measuring absorbance at $660 \mathrm{~nm}$ and using colloidal chitin as a 
standard. Measurement of enzyme activity was finalized by using the turbidimetric method. The calculation was: The colloidal chitin concentration $=$ colloidal chitin concentration before hydrolysis - colloidal chitin concentration after hydrolysis. Protein concentration was determined by Bradford method (1976) using bovine serum albumin as standard.

\section{Characteristic of chitinase activity by $\mathrm{pH}$ and temperature}

The effect of $\mathrm{pH}$ on chitinase activity was determined by measuring the activity at $30^{\circ} \mathrm{C}$ and the $\mathrm{pH}$ range of $(\mathrm{pH}$ 5.0 to 8.0 ) using $1 \%$ colloidal chitin as a substrate under standard assay conditions. The following buffers used were: $50 \mathrm{mM}$ sodium citrate buffer $(\mathrm{pH} 5.0$ and 6.0), and $50 \mathrm{mM}$ sodium phosphate buffer $(\mathrm{pH} 6.0$ to 8.0). The optimum temperature was determined by incubating the enzymatic reaction mixtures within the temperature range of 20 to $60{ }^{\circ} \mathrm{C}$ with $10^{\circ} \mathrm{C}$ intervals, using the previous observation that $\mathrm{pH}$ optimum of activity. The stability of chitinase activity was investigated by incubating the enzyme activity within optimum $\mathrm{pH}$ and temperature for 30 min (Purkan et al., 2016).

\section{In vitro antagonistic activity assay by the crude} enzyme of $\beta$-glucanase and chitinase production

In vitro assay was performed using agar well diffusion method to detect which antifungal enzyme ( $\beta$-glucanase and chitinase) were active against $G$. boninense. These assessments were comprised of two parts: In the first part, crude extract of $\beta$-glucanase $(100 \mu \mathrm{L})$ or crude extract of chitinase $(100 \mu \mathrm{L})$ was transferred into the wells, which far away from center of a fresh PDA plates $(2.5 \mathrm{~cm})$, and an agar plug $(6 \mathrm{~mm}$ diameter) of $G$. boninense was then placed centrally on a PDA plate, which the wells containing antifungal enzymes. One well containing sterile distilled water had used as negative control and one well containing salicylic acid $(0.4 \mathrm{mg} / \mathrm{mL})$ was used as positive control. Subsequently, antagonistic activities of $\beta$-glucanase or chitinase enzymes were assessed qualitatively. In the second part, these entire tests for antagonistic activity were incubated at room temperature and it was possible to observe in all growth directions as well as daily visual observation until day 5 of incubation. To identify a potential role of both enzymes to inhibit the growth of $G$. boninense was assessed for their antagonistic effect on $G$. boninense within all parameters that were investigated by measuring the mycelium of $G$. boninense colony in the direction towards the antagonist colony (R2). The data were later transformed into percentage inhibition of radial growth (PIRG) in relation to the radial growth of $G$. boninense in the control plate (R1) which would be estimated by the following equation:

$\operatorname{PIRG}(\%)=\frac{\mathrm{R} 1-\mathrm{R} 2}{R 1} \times 100$
Where, $\mathrm{R} 1$ is the length of radial growth of fungus $(2.5$ $\mathrm{cm}$ ) in control sets and $\mathrm{R} 2$ is the radial growth of the fungus-treated with antagonistic activity (Bivi et al., 2010). The experiment was conducted around 5 times.

\section{Culture media and bacterial metabolite extraction from Bacillus subtilis}

The active inoculums of $B$. subtilis (10\%) were incubated into fresh $50 \mathrm{~mL}(\mathrm{w} / \mathrm{v})$ of nutrient broth (NB) mediums with a pH 7.0 in 100 mL Erlenmeyer flasks and incubated on a temperature shaker at $37{ }^{\circ} \mathrm{C}, 150 \mathrm{rpm}$ (ZHWY200B/200D). Fifty milliliter culture broth from 3 replicates were collected for 28 h, 48 h, 72 h and 96 h of incubation. The cell culture was harvested by centrifugation at 4500 rpm for $40 \mathrm{~min}$ at $4{ }^{\circ} \mathrm{C}$ by Ramyabharathi and Raguchander (2014). Different type of solvents (methanol, ethyl acetate, and hexane) was used for extracting antifungal metabolites from the bacterial cellfree supernatant. A total of $5 \mathrm{~mL}$ of cell-free supernatants were combined with $5 \mathrm{~mL}$ of each solvent (1:1 ratio) to a final volume of $10 \mathrm{~mL}$ in $25 \mathrm{~mL}$ falcon tubes. Subsequently, these samples were incubated at room temperature for overnight with shaking at $150 \mathrm{rpm}$ speed. After the overnight incubation, the extraction of all supernatants with a mixture of each solvent was centrifuged at $4500 \times g$ for $40 \mathrm{~min}$ at $4^{\circ} \mathrm{C}$ and transferred into $15 \mathrm{~mL}$ falcon. After centrifugation, all the solvent extracts that contained metabolite compounds were directly assayed for their antifungal metabolite activity, an in vitro assay.

\section{In vitro antifungal activities of bacterial metabolite} extract from $B$. subtilis against $G$. boninense

The antifungal metabolites activity of $B$. subtilis was obtained by using the extraction method of maceration. According to Lenny (2006) maceration is done by soaking the samples in an organic solvent at a certain time at room temperature. The process is commonly used to extract metabolites compounds. The basic principle of maceration is soaking the sample in solvents which will lyse the cells because of the differences of pressure inside and outside of the cells. Thus, metabolites produced by $B$. subtilis could dissolve in solvents.

The effectiveness of all the solvent extracts was assayed for their antifungal activity by paper disc diffusion method (Alemu and Alemu, 2013). A mycelial plug of 6 $\mathrm{mm}$ diameter from 3 days old of $G$. boninense culture was cut and transferred to the center of PDA plates. The sterile filter paper discs were immersed in solvent extracts for $20 \mathrm{~min}$ and additionally placed onto PDA plates which containing the fungal pathogen. The filter paper discs were placed in $2.5 \mathrm{~cm}$ away from the agar plug of the fungal pathogen. One filter paper disc without solvent extracts were used as a control. All the plates were incubated at room temperature for 4 days of incubation. The inhibition of antifungal activity was investigated as a zone of mycelial growth of $G$. boninense on PDA plates, the inhibition zones were visibly observed as well as daily 
visual observation until day 4 of incubation. The percentage of inhibition of radial growth was estimated following the equation below:

Delta Inhibition Diameter $(\boldsymbol{\Delta})=\mathrm{SD}-\mathrm{ED}$

Net Inhibition Diameter (NID) $=\mathrm{NCD}-\mathrm{ED}+\boldsymbol{\Delta}$

Net Inhibition $(\mathrm{NI}) \%=\frac{\mathrm{NCD}-\mathrm{NID}}{\text { NCD }} \times 100$

PIRG $(\%)=100-\mathrm{NI}$

Where SD is Solvent Diameter; ED is extraction diameter, and NCD (Negative Control Diameter) is a length of radial growth of fungus $(2.5 \mathrm{~cm})$ in control sets.

\section{Statistical analysis}

The data were statistically analyzed for significance by ANOVA using Minitab version 6.0 systems for Windows and a value of $p \leq 0.05$ was considered statistically significant.

\section{RESULTS}

\section{Bacillus subtilis growth and enzyme production}

\section{Bacillus subtilis growth and $\beta$-glucanase production}

The determination of optimum condition $\beta$-glucanase activity was done by testing some variables: measurement of $B$. subtilis growth, measurement of protein content and testing $\beta$-glucanase activity against incubation time fermentation (enzyme production). From the experiment, it was found that the $\mathrm{OD}_{600}$ of $B$. subtilis culture started increasing exponentially from 0.0475 to 0.7655 at adaptation phase on the hour- 0 until $8 \mathrm{~h}$ of incubation (Figure 1). Subsequently, the growth increased up to $28 \mathrm{~h}$ at an $\mathrm{OD}_{600}$ of 1.484 and slowly decreased at $48 \mathrm{~h}$ of incubation. The growth rate of $B$. subtilis was suspected to decrease, due to a progressive decrease in substrate availability per cell over time caused by microbial consumption.

In addition to the $\beta$-glucanase enzyme, $B$. subtilis produced $\beta$-glucanase enzyme at the beginning of cell growth and the highest enzyme activity increased when cells entered the stationary phase (Figure 1). Dewi et al., (2017) reported that $\beta$-glucanase produced by $B$. subtilis SAHA 32.6 was secreted in the log phase when the media contains glucose and exhibited high activity when bacterial cells entered the stationary phase, which contains glucan as the carbon source. $\beta$-glucanase activity increased when cells stopped growing after lack of glucose. $\beta$-glucanase activity increased only when cells stopped growing during glucose or amino acid starvation (Stulke et al., 1993). In this experiment, the $\beta$-glucanase enzyme of $B$. subtilis was secreted after $4 \mathrm{~h}$ of incubation $(2.110 \mathrm{U} / \mathrm{mg})$ and increased to $3.174 \mathrm{U} / \mathrm{mg}$ after $20 \mathrm{~h}$ of incubation. The specific $\beta$-glucanase enzyme activity increased to $4.222 \mathrm{U} / \mathrm{mg}$ after $28 \mathrm{~h}$ of incubation and declined steadily (Figure 1). Therefore, the addition of glucose (yeast extract and tryptone) and glucan (laminarin) as substrate caused $\beta$-glucanase activity to be the highest at stationary phase. The result in Figure 1 showed that the highest $\beta$-glucanase activity by $B$. subtilis was achieved at $28 \mathrm{~h}$ of incubation. So, the time was used for the cultivation process to harvest the enzyme and to find out the optimum $\beta$-glucanase activity at different $\mathrm{pH}$ and temperature.

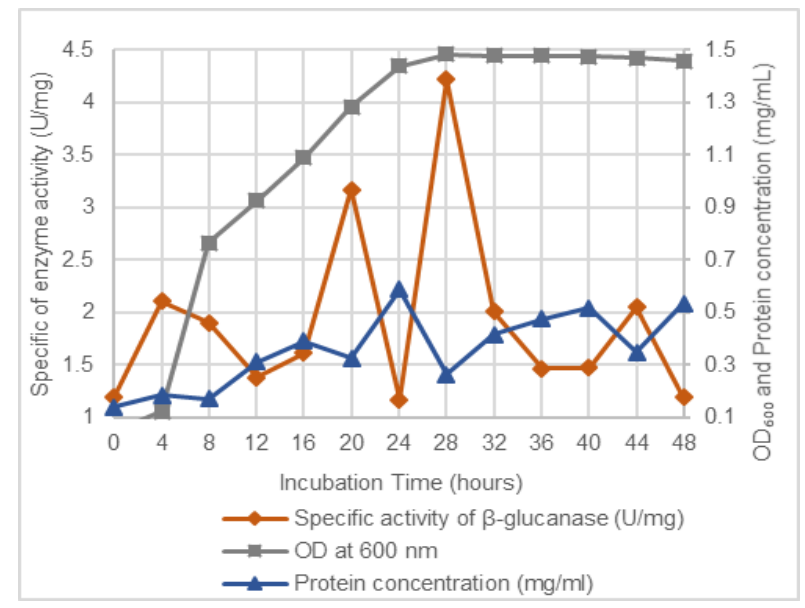

Figure 1: Production of $\beta$-glucanase and protein concentration by $B$. subtilis on $\beta$-glucanase medium containing $1 \%$ laminarin at $37^{\circ} \mathrm{C}$ and $\mathrm{pH} 7.0$.

\section{B. subtilis growth and chitinase production}

The growth and production of chitinase by $B$. subtilis was investigated in nutrient broth (NB) growth media which contained $1 \%$ colloidal chitin as substrate $(\mathrm{pH} 7.0)$ at 37 ${ }^{\circ} \mathrm{C}$ on the shaker incubator at $170 \mathrm{rpm}$. The crude enzyme was analyzed for chitinase activity every $4 \mathrm{~h}$ until $48 \mathrm{~h}$ incubation. The growth rate of $B$. subtilis strains $\mathrm{E}-1$ increased from 0 to $8 \mathrm{~h}$ of incubation. At that time the growth was relatively stable up to $16 \mathrm{~h}$ of incubation and decreased after $16 \mathrm{~h}$ of incubation (Figure 2). This result was supported by Hogg (2005) who stated that the increase in the number of cells during bacterial growth indicated that the bacteria utilized the nutrient source in the medium as a component which was required for its growth, while the decrease in the number of bacterial cells in the growth curve occurred after the active phase of bacterial growth (called stationary phase) because the bacteria will produce secondary metabolites that are toxic.

The chitinase enzyme activity after $4 \mathrm{~h}$ of incubation was $0.0312 \mathrm{U} / \mathrm{mL}$ and relatively increased to $0.0514 \mathrm{U} / \mathrm{mL}$ after $8 \mathrm{~h}$ of incubation. The enzyme activity descended after $8 \mathrm{~h}$ of incubation. The result in Figure 2 showed that the chitinase enzyme activity was high before the cell growth entered the stationary phase. Consequently, this study presented that $B$. subtilis could produce chitinase enzyme at the early stage of fermentation in NB growth media which contained $1 \%$ colloidal chitin as the carbon source. The chitinase activity decreased before the cell 
entry to stationary phase. Jholapara et al. (2013) reported that colloidal chitin served as the best carbon source to produce chitinase, meanwhile another carbon source such as glucose served to inhibit chitinase biosynthesis despite supporting prosperous cell growth of the $B$. subtilis in media. Thus, NB media was used for bacterial cell growth, but it was not fulfilling all requirements necessary for antibiotic production. However, the highest chitinase activity was found after $8 \mathrm{~h}$ of incubation.

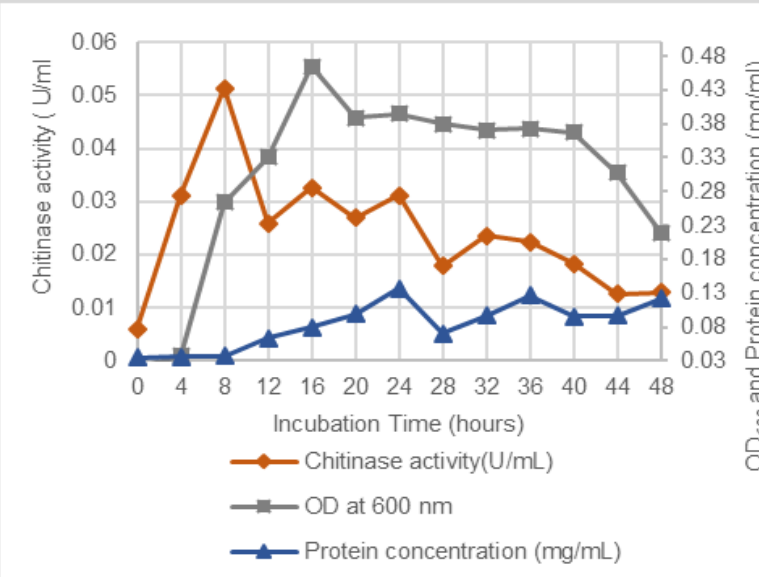

Figure 2: Production of chitinase and protein content produced by $B$. subtilis on NB medium containing $1 \%$ colloidal chitin at $37^{\circ} \mathrm{C}$ and $\mathrm{pH}$ 7.0.

\section{Characteristic of $\beta$-glucanase and chitinase activity by $\mathrm{ph}$ and temperature}

Effect of $\mathrm{pH}$ value on the crude enzyme of $\beta$-glucanase and chitinase activity of $B$. subtilis

The characterization of $\beta$-glucanase and chitinase crude extracts by $\mathrm{pH}$ and temperature were described in Figures 3 and 4 . Effect of $\mathrm{pH}$ on the activity of $\beta$ glucanase enzyme has shown that the specific enzyme activity increased with the increasing $\mathrm{pH}$ up to $\mathrm{pH} 7.5$ (Figure 3). The specific of $\beta$-glucanase activity at $\mathrm{pH} 5.5$ was $4.25 \mathrm{U} / \mathrm{mg}$ which rose sharply to $6.36 \mathrm{U} / \mathrm{mg}$ at pH 7.0 and then continued increasing until $\mathrm{pH} 7.5$ with an activity of $7.04 \mathrm{U} / \mathrm{mg}$ which was considered the optimum $\mathrm{pH}$ of the $\beta$-glucanase of crude enzyme. Furthermore, with increasing $\mathrm{pH}>7.5$, specific $\beta$-glucanase activity was decreased to $4.75 \mathrm{U} / \mathrm{mg}$ at $\mathrm{pH} 8.0$.

Based on the result of this experiment, it could be pointed out that $\mathrm{pH} 7.5$ was the optimum $\mathrm{pH}$ of $\beta$ glucanase activity. The previous study reported by Wijaya (2015) demonstrated that the $\beta-1,3$ glucanase activity from $B$. licheniformis BKA53 has an optimum $\mathrm{pH} 7.5$ and optimum temperature at $45{ }^{\circ} \mathrm{C}$. Beauvais et al. (2001) also reported that the hydrolysis enzyme which degrades $\beta-1,3$ glucanase can generally work in the neutral $\mathrm{pH}$ conditions by breaking down a glucan to a polysaccharide made of several glucose sub-units. This shows that, high $\mathrm{pH}$ would influence reaction products, and inhibits the $\beta$ - glucanase reaction. Changing the $\mathrm{pH}$ value will not only affect the shape of $\beta$-glucanase, it can also cause changes to the charge properties of the substrate (laminarin). Consequently, either enzyme substrate could not bind to the active site or it could not undergo catalysis (Nielsen et al., 2001 and Ali et al., 2014). In this experiment, a $\mathrm{pH} 8.0$ may affect dramatically both the enzyme conformation and substrate properties.

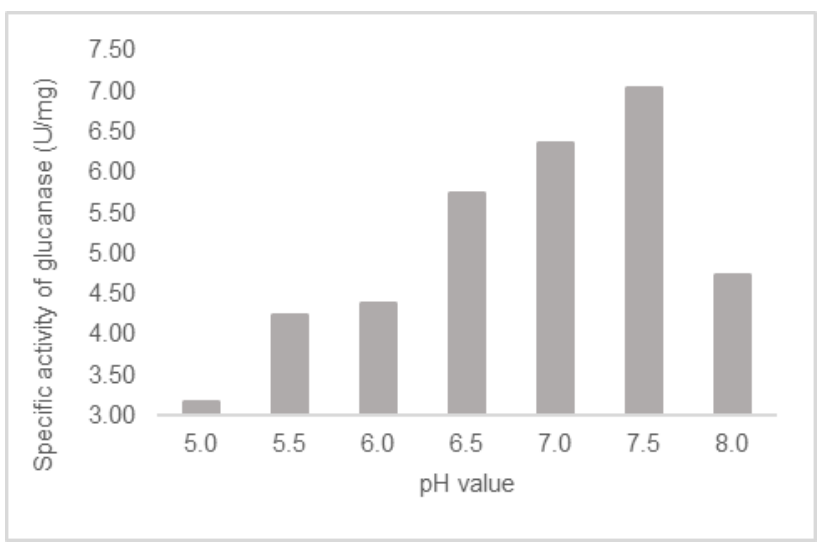

Figure 3: Effect of different $\mathrm{pH}$ value on the specific activity of $\beta$-glucanase by $B$. subtilis. The activity was measured at $37^{\circ} \mathrm{C}$.

Effect of the $\mathrm{pH}$ on chitinase activity was shown in Figure 4. The result showed that the $\mathrm{pH}$ increased the specific activity of the crude enzyme up to a maximum of $0.011 \mathrm{U} / \mathrm{mg}$-protein at $\mathrm{pH} 6.0$, but the enzyme activity decreased in $\mathrm{pH}$ higher than $\mathrm{pH}$ 6.0. Purkan (2016) reported that the chitinase activity by fungi Aspergillus niger has optimum $\mathrm{pH}$ at $\mathrm{pH} 6.0$ and the optimum temperature of $40{ }^{\circ} \mathrm{C}$. The enzyme activity was determined by the presence of donor protons and donor acceptors on the degree of ionization, obtained at optimum pH reported (Wilson and Walker, 2005). Moreover, the $\mathrm{pH}$ also affects the solubility of the substrate and Farabee (2001) reported that extreme $\mathrm{pH}$ caused changes in the structure of the enzyme and then decrease the effectiveness and efficiency of enzyme activity.

Effect of temperature on $\beta$-glucanase and chitinase activity of the crude enzyme of $B$. subtilis

Temperature is one of the factors that affect the enzyme activity. Changing temperature can lead to protein or enzyme folding so that the enzyme active site is in the right position to catalyze substrate.

The experiment result showed that the specific activity of $\beta$-glucanase increased at $35^{\circ} \mathrm{C}$ with a specific activity of $0.726 \mathrm{U} / \mathrm{mg}$-protein, rising to $0.763 \mathrm{U} / \mathrm{mg}$ at $40{ }^{\circ} \mathrm{C}$ and further to $1.680 \mathrm{U} / \mathrm{mg}$ at $45^{\circ} \mathrm{C}$. The specific activity of the enzyme decreased with increasing temperature to $50{ }^{\circ} \mathrm{C}$ $(0.717 \mathrm{U} / \mathrm{mg})$ and declined steadily to $0.351 \mathrm{U} / \mathrm{mg}$ at 55 ${ }^{\circ} \mathrm{C}$ (Figure 5). Increasing the incubation temperature of an 
enzyme could cause the increase of enzyme activity. This is due to the increased speed of thermal motion of enzyme molecules, which increased the numbers of molecules that have enough energy to reach the transition state (Bollage and Edelstein, 1991). Based on the data, it can be concluded that the maximum specific activity of $\beta$-glucanase at $45{ }^{\circ} \mathrm{C}$ was observed when hydrolyzing laminarin substrate.

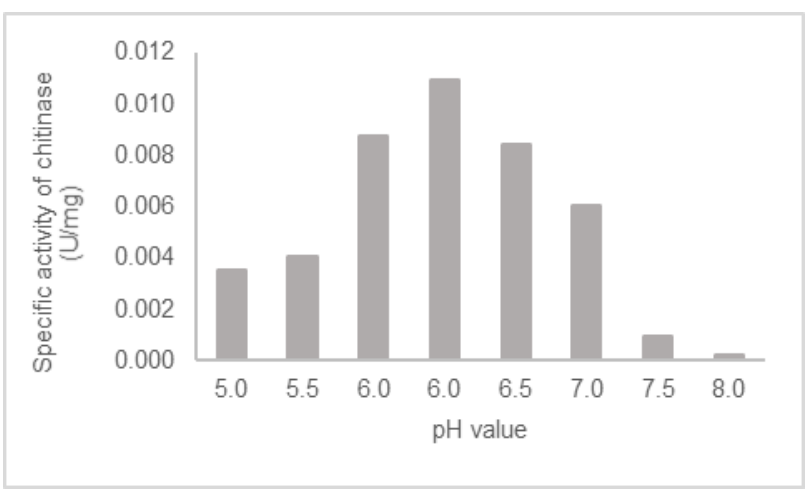

Figure 4: Effect of different $\mathrm{pH}$ value on the specific activity of chitinase by $B$. subtilis. The activity was measured at $37^{\circ} \mathrm{C}$.

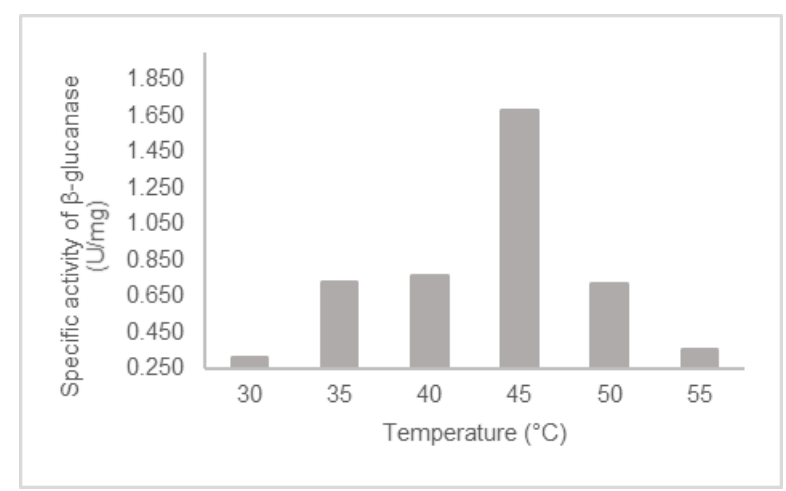

Figure 5: Effect of different temperature value on the $\beta$ glucanase activity of the crude enzyme by $B$. subtilis. The activity was measured at $\mathrm{pH} 7.0$.

The chitinase activity of the crude enzyme at various temperatures increased dramatically with evaluation of temperature up to a maximum activity of $0.045 \mathrm{U} / \mathrm{mg}$ protein at $40{ }^{\circ} \mathrm{C}$, but the activity of the enzyme was reduced when the temperature increased (Figure 6). According to Lestari et al. (2017), the optimum temperature of chitinase activity from B. subtilis B 298 was achieved at $40{ }^{\circ} \mathrm{C}$. The similar optimum temperature was obtained for the chitinase activity of Bacillus sp. R2 (Cheba et al., 2016) and Pseudomonsa aeruginosa K-187 (Wang and Change, 1997). The optimum temperature of chitinase activity from $B$. subtilis is not sufficiently high; this is because chitinase is classified as the mesophilic enzyme (Fardiaz, 1989). So, the result of chitinase activity can be assumed as not resistant to heat.

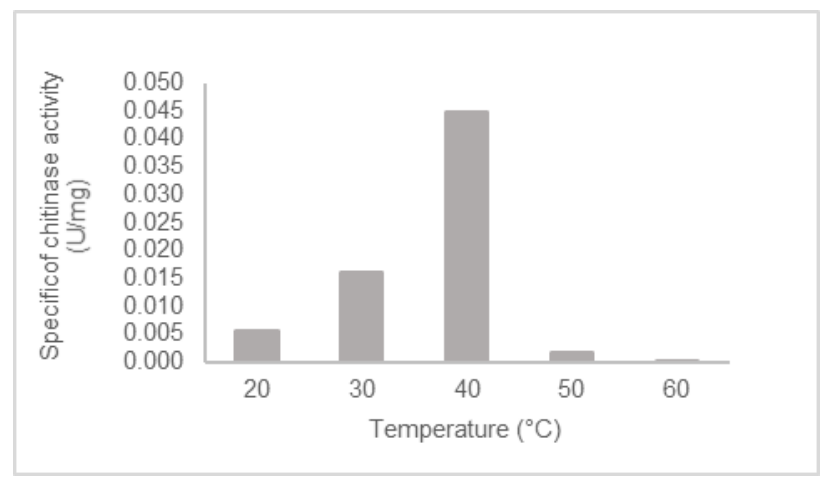

Figure 6: Effect of different temperature value on chitinase activity of $B$. subtilis. The enzyme activity was determined at $\mathrm{pH} 6.0$.

\section{In vitro antifungal activity on $G$. boninense by $\beta$ - glucanase and chitinase enzyme from $B$. subtilis}

The effectiveness of antagonist activity against the mycelial growth of $G$. boninense by $\beta$-glucanase and chitinase enzyme from $B$. subtilis was investigated according to the best incubation time and physical characteristics of $\beta$-glucanase and chitinase products from the previous experiment. $B$. subtilis produced highest $\beta$-glucanase activity at $28 \mathrm{~h}$ incubation, and the optimum $\mathrm{pH}$ and temperature of $\beta$-glucanase were 7.5 and $45^{\circ} \mathrm{C}$ respectively. Meanwhile, $B$. subtilis produced highest chitinase activity at $8 \mathrm{~h}$ incubation, With an optimum $\mathrm{pH}$ of 6.0 and temperature of $40^{\circ} \mathrm{C}$.

Inhibition of the growth of fungal pathogen of $G$. boninense was detected in vitro assay by using the crude enzyme $(100 \mu \mathrm{L})$ of $\beta$-glucanase and $(100 \mu \mathrm{L})$ chitinase using an agar well-diffusion method. The experiment results showed that the $\beta$-glucanase of crude enzyme significantly inhibited the mycelial growth of $G$. boninense on agar plates after 3 days of incubation and increased inhibition until 5 days of incubation (Figure 7).

In contrast, the ability of crude chitinase inhibited the growth of $G$. boninense until 4 days of incubation by $10.74 \%$ when compared with control and decreased after 5 days of incubation (Figure 7). Furthermore, chitinase was not significantly different $(P>0.05)$ in inhibiting the growth of $G$. boninense compared with control. It was allegedly because of the low activity of chitinase enzyme, and the cell wall of $G$. boninense also contained glucan and other compounds, which could block chitinase enzyme in hydrolyzing or degrading the cell wall of $G$. boninense.

The effectiveness of the $\beta-1,3$-glucanase enzyme is related to the ability of an enzyme that only specifically degrade the glucan molecules of the fungal cell wall. Therefore the ability of $\beta-1,3$-glucanase enzyme to degrade the cell wall components is weakened. As a result, the growth inhibition effect to $G$. boninense has not maximized. Wrobel et al. (2014) reported that besides glucans and chitins, fungal pathogen cell walls also contain other components such as proteins and lipids 
which cover the cell wall of fungi that can block the degradation of the main components of fungal cell wall. For this reason, the effectiveness of $\beta$-glucanase and chitinase to inhibit the growth of $G$. boninense was decreased after 5 days of incubation on PDA agar medium.

Yurnaliza (2001) also stated that chitinase enzyme activity of Actinomycetes RKt-5 showed no inhibition growth of $F$. oxysporum because the components of the fungi cell wall were not entirely chitin, consequently chitinase was unable to hydrolyze other cell wall components such as glucan or proteins. There were three factors, which can influence the effectiveness of lytic enzyme of Actinomycetes RKt-5 in inhibiting the growth of $F$. oxysporum. These factors were low enzyme concentration; the fungal cell walls contain proteins and lipids that inhibited chitinase activity and loss or appearance of other compounds that play a role during the test. Thus, the specific activity of chitinase was low since the cell wall of $G$. boninense also contained glucan, proteins, and lipids. Consequently, the inhibition rate of chitinase on $G$. boninense growth in vitro assay was also low.

The finding of this study concluded that the crude enzyme of $\beta$-glucanase could inhibit the growth of $G$. boninense better than the crude enzyme of chitinase, $47.75 \%$ compared to $1.12 \%$ inhibition, respectively, which was compared with control after 5 days of incubation (Figures 7-9). It showed that $\beta$-glucanase was more effective in inhibiting $G$. boninense compared to chitinase as the specific activity of $\beta$-glucanase was higher than chitinase in this study. According to Fesel and Zuccaro (2016) chitins are located at the apex and in the inner parts of the lateral wall, so it is more susceptible to chitinase at the tip than in the subapical part. Whereas, glucans are located on the outer layer where they are degraded by $\beta$-glucanase (Kim and Yun, 2006).

This experiment was comparable to Vidhyasekaran (1997) results which reported that $\beta-1,3$ glucanase inhibited the growth of $F$. solani fsp. sipi at $250 \mu \mathrm{g} / \mathrm{mL}$, while chitinase did not inhibit the fungi. The results suggested an absolute requirement for that concentration of enzyme activities to cause inhibition of the fungi, which may occur in infected pea pod tissues. Accordingly, the concentration of specific activity of $\beta$-glucanase was higher than chitinase, $1.680 \mathrm{U} / \mathrm{mg}$ to $0.045 \mathrm{U} / \mathrm{mg}$, respectively.

\section{Result of extraction and the effectiveness of antifungal metabolite from $B$. subtilis}

Antifungal metabolites had been successfully extracted from the bacterial cell culture at $28 \mathrm{~h}, 48 \mathrm{~h}, 72 \mathrm{~h}$ and $96 \mathrm{~h}$ incubation in NB at $37^{\circ} \mathrm{C}, \mathrm{pH} 7.0$. Madigan et al. (2012) suggested that bacteria started producing metabolites in the last stationary phase of bacteria growth. Metabolite extraction was done by using different solvents namely methanol, ethyl acetate, and hexane.

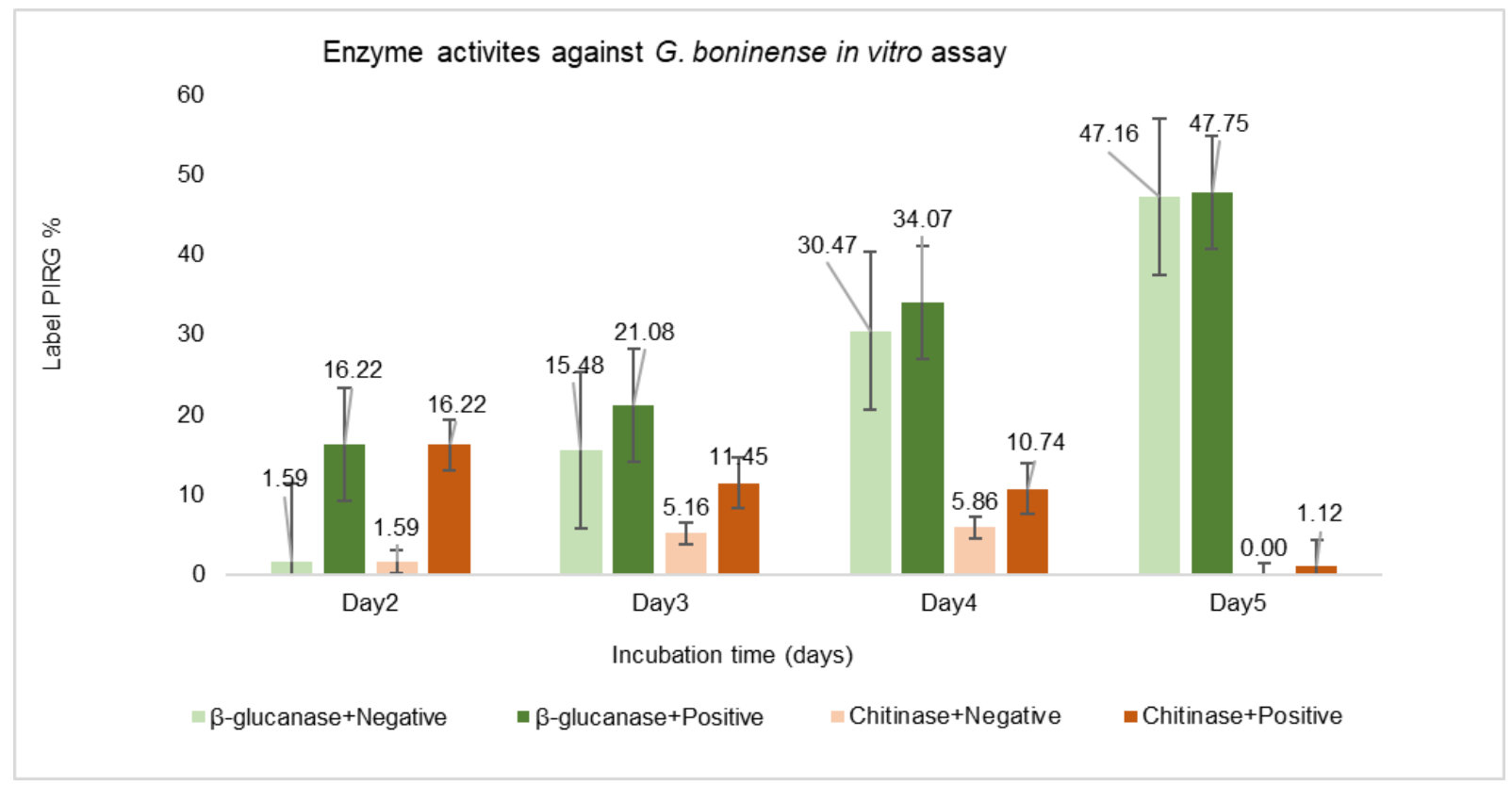

Figure 7: Inhibition of the mycelial growth of $G$. boninense by $\beta$-glucanase and chitinase of $B$. subtilis strains $E$ - 1 on PDA medium (after 2-5 days of incubation). Sterile distilled water as a Negative control and Salicylic acid $(0.4 \mathrm{mg} / \mathrm{mL})$ as positive control. 

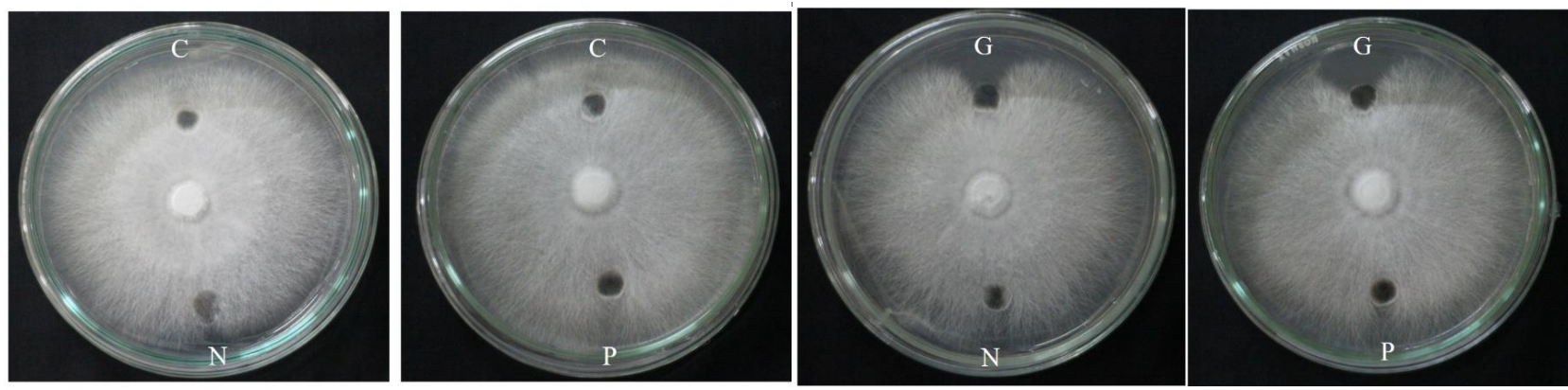

Figure 9: Antagonistic activity of $\beta$-glucanase and chitinase derived from $B$. subtilis against mycelium of $G$. boninense. Growth inhibition of fungal mycelia was examined in dual culture assay on agar plates at 5 days of incubation: (N) negative control; $(P)$ positive control; $(G) \beta$-glucanase enzyme; $(C)$ chitinase enzyme.

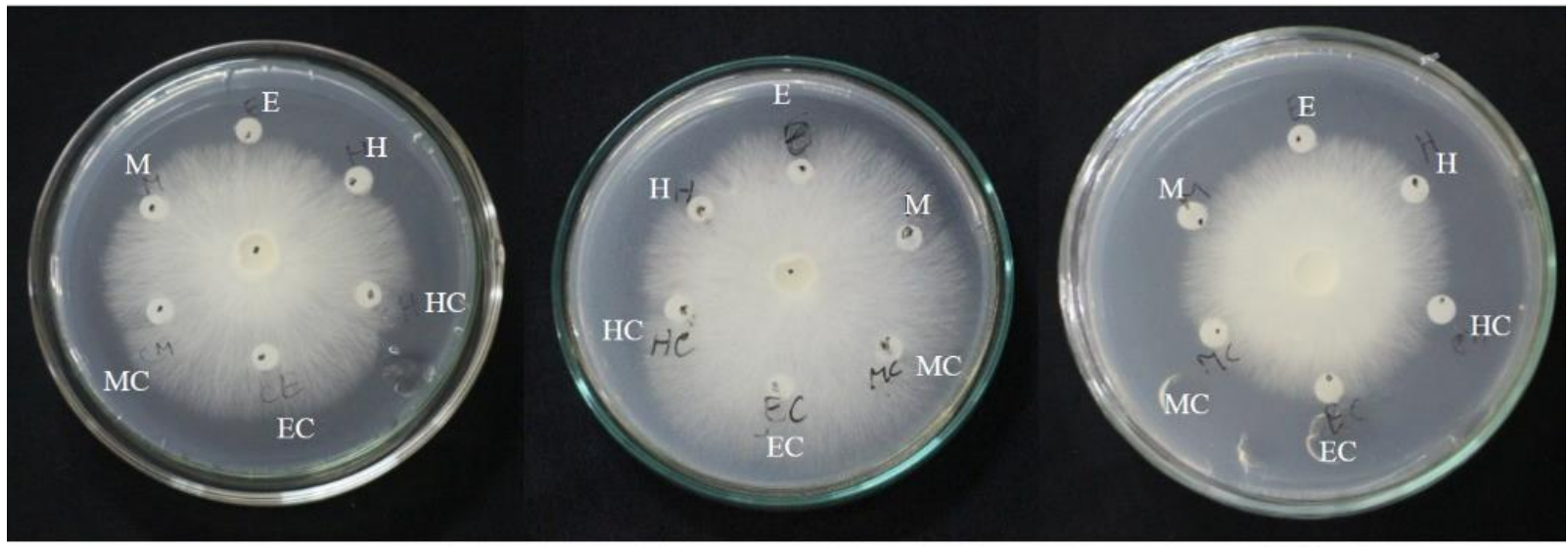

48 hours

72 hours

96 hours

Figure 10: Antifungal metabolites extracted from $48 \mathrm{~h}, 72 \mathrm{~h}$ and $96 \mathrm{~h}$ cultures of $B$. subtilis strains $\mathrm{E}-1$ against $G$. boninensel. Growth inhibition of fungal mycelia was examined in dual culture assay on agar plates at 4 days of incubation. (C) Control; (M) methanol with metabolites extracted; (E) ethyl acetate with metabolites extracted; $(\mathrm{H})$ hexane with metabolites extracted.

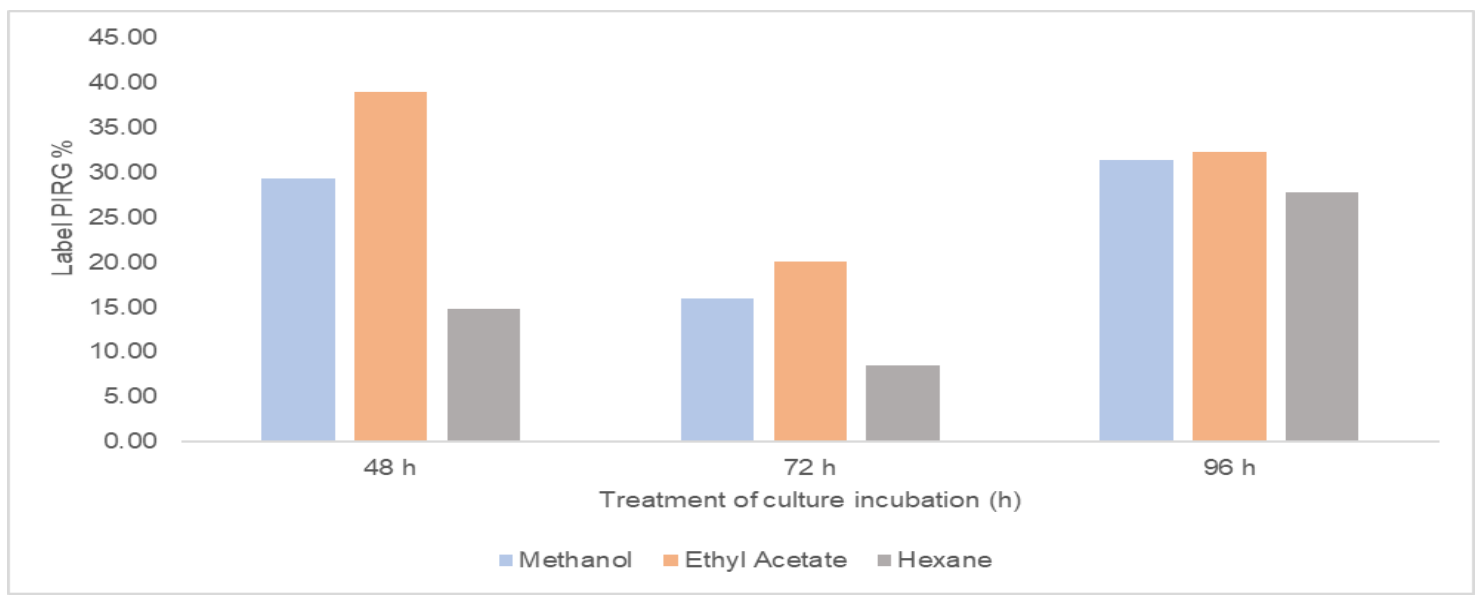

Figure 11: Comparison of antifungal metabolites produced by difference time of $B$. subtilis cultures to inhibit the mycelial growth of $G$. boninense on PDA plates at $27 \pm 2{ }^{\circ} \mathrm{C}$. Growth inhibition of fungal mycelia was examined in dual culture assay on agar plates at 4 days of incubation. 
The results showed that metabolite extracts of $B$. subtilis produced clear inhibition zone (Figure 10) with the highest inhibition of $G$. boninense growth was obtained at $48 \mathrm{~h}$ cultures and metabolites extracted by ethyl acetate solvent which gave $38.91 \%$ inhibition after 4 days incubation (Figure 11). Ridwan (2005) reported that the solvent acetone and ethyl acetate were common solvents used in the extraction process which play a role as semipolar solvents. Ramyabharathi and Raguchander (2014) isolated an efficient strain of $B$. subtilis EPC016 from the cotton plant that produced both surfactin and Iturin antifungal compounds, would play a major role in $F$. wilt suppression.

In another study by Darwiati (2009) stated that the compounds with the same polarity will be easily dissolved in a solvent which has similar polarity. The previous study by Chen and Juang (2008) also reported that ethyl acetate is the best extraction of surfactin which had a recovery of $99 \%$ and resulted in purify of $60 \%$, whereas methanol and hexane are less suitable for amounts of surfactin are solved when compared with ethyl acetate solvent. Hence, in these study metabolites compounds contained in $B$. subtilis were trended to semi-polar components. Thus, the ethyl acetate solvent showed highest attached metabolites of $B$. subtilis to inhibit the growth of $G$. boninense as an antifungal metabolite. However, antifungal metabolite extracted with each solvent was shown the ability to inhibit the growth of $G$. boninense when compared with its control (Figures 10 and 11).

The findings of the present study demonstrated that the maximum antifungal metabolite activity of $B$. subtilis was obtained from $48 \mathrm{~h}$ cultures. Although the good inhibition activity was also found at 48 and $96 \mathrm{~h}$ cultures. The result of $48 \mathrm{~h}$ cultures inhibited the mycelial growth of G. boninense to about $38.91 \%$, when compared to $32.30 \%$ and $20.04 \%$ after $96 \mathrm{~h}$ and $72 \mathrm{~h}$ cultures, respectively (Figure 11). Whereas, crude antifungal metabolites extracted at $28 \mathrm{~h}$ of incubation, failed to inhibit the growth of $G$. boninense (data not shown).

Based on the data in Figure 11, the solvent ethyl acetate had the best ability to attach metabolite produced by $B$. subtilis when compared with methanol and hexane solvents. Thus, antifungal metabolite showed the highest activity to inhibit the mycelial growth of fungi $G$. boninense at $48 \mathrm{~h}$ cultures, especially metabolites that were extracted by ethyl acetate as a semi-polar solvent, followed by methanol and hexane. Three kinds of solvents showed high inhibition activity at 48 cultures and the inhibition activity was reduced at $72 \mathrm{~h}$ and increased again at $96 \mathrm{~h}$ cultures. This was the correlation that the growth of $B$. subtilis into the nutrient broth mediums influenced changing the $\mathrm{pH}$ of the mediums as they produced metabolites while they were growing (Figure 11). As the result showed that the inhibition activity was relatively high at $48 \mathrm{~h}$ and $96 \mathrm{~h}$ cultures and at $72 \mathrm{~h}$ culture was low inhibition activity, so $B$. subtilis released metabolites to neutralize the $\mathrm{pH}$ to its growth conditions and then started growing vigorously which made the mediums altered. Gesheva et al. (2005) found that the $\mathrm{pH}$ changes due to the release of metabolites in nutrient broth (NB) mediums and cause the metabolite productions active against bacterial isolates. Thus, the $\mathrm{pH}$ could have a direct effect on the metabolite productions which produced by $B$. subtilis at difference time.

The effectiveness of antifungal metabolite extracted from $B$. subtilis against $G$. boninense was confirmed by the inhibition of the mycelial growth in different solvent extracts compared to the control on PDA plates. The results showed that the mycelial growth of fungi on the side of the control paper disc grew thicker than on the side of the paper disc containing dissolved metabolites extracted by different solvent (Figure 10). So, metabolites produced by $B$. subtilis played a role as antifungal because it inhibited the mycelia growth of $G$. boninense on PDA plates. This was supported by Leelasuphakul et al. (2008) statement that antimicrobial compounds and antifungals produced by microorganisms might play a role in inhibiting the growth of fungi.

\section{CONCLUSION}

The maximum inhibition rate $(47.75 \%)$ of $G$. boninense by the $\beta$-glucanase activity of $B$. subtilis was achieved after $28 \mathrm{~h}$ of culture incubation and enzymatic treatment condition of $\mathrm{pH} 7.5$ and temperature $45^{\circ} \mathrm{C}$. The maximum inhibition rate $(10.74 \%)$ of $G$. boninense by chitinase activity of $B$. subtilis was achieved after $8 \mathrm{~h}$ of culture incubation and enzymatic treatment condition at $\mathrm{pH} 6.0$ and $40{ }^{\circ} \mathrm{C}$. Incubation of $B$. subtilis over $48 \mathrm{~h}$ produced antifungal metabolite which can inhibit the growth of $G$. boninense the most and ethyl acetate was the best solvent to extract the antifungal metabolites with the inhibition rate of $38.91 \%$. It can be concluded that $\beta$ glucanase, chitinase, and metabolites produced from $B$. subtilis which have antifungal activity against $G$. boninense are expected to be used in the medical field against fungal infections and in agriculture sector as biological agents.

\section{ACKNOWLEDGEMENTS}

The authors are grateful to Kemitraan Negara Berkembang (KNB) Scholarship for a technical support manager. I would also like to thank PL Astra Agro Lestari for research foundation and School of Life Science and Technology for student financial assistance.

\section{REFERENCES}

Ajidarma, E. (2012). Isolasi dan identifikasi bakteri endofit akar kelapa sawit (Elaeis guineensis) antagonis terhadap fungi patogen Ganoderma boninense. Program Studi Sarjana Mikrobiologi, Sekolah IImu Dan Teknologi Hayati, Institut Teknologi Bandung.

Alemu, F. and Alemu, T. (2013). Antifungal activity of secondary metabolites of Pseudomonas fluorescens isolates as a biocontrol agent of chocolate spot disease (Botrytis fabae) of faba bean in Ethiopia. 
African Journal of Microbiology Research 7(47), 53645373.

Alfonzo A., Conigliaro G., Torta L., Burruano S. and Moshetti G. (2009). Antagonism of Bacillus subtilis strains AG1 against vine wood fungal pathogens. Phytopathologia Mediterranea 48, 155-158.

Ali, Z. A., Yahya, A. G. I. and Jabir, A. W. S. (2014). The effect of static magnetic field on growth and biochemical indices of five fungal generals. Journal of Biotechnology Research Center 8(3), 28-36.

Arras, G. (1993). Inhibition of postharvest fungal pathogens by Bacillus subtilis strains isolated from citrus fruit. Advances in Horticultural Science 7(3), 123-127.

Arras, G. and Dhallewin, G. (1994). In vitro and in vivo control of Penicillium digitatum and Botrytis cinereal in citrus fruit by Bacillus subtilis strains. Agricoltura Mediterranea 124(1), 56-61.

Bradford, M. M. (1976). A rapid and sensitive method for the quantitation of microgram quantities of protein utilizing the principle of protein-dye binding. Analytical Biochemistry 72(1-2), 248-254.

Benitez, T., Rincon, A. M., Limon M. C. and Codon, A. C. (2004). Biocontrol mechanisms of Trichoderma strains. International Microbiology 7, 249-260.

Beauvais, A., Bruneau, J. M., Mol, P. C., Buitrago, M. J., Legrand, M. J. and Latge, J. P. (2001). Glucan synthase complex of Aspergillus fumigatus. Journal of Bacteriology 183(7), 2273-2279.

Bivi, M. R., Farhana, M. S. N., Khairulmazmi, A. and Idris, A. (2010). Control of Ganoderma boninense: A causal agent of basal stem rot disease in oil palm with endophytes bacteria in vitro. International Journal of Agriculture and Biology 12(6), 833-839.

Bollage, D, M. and Edelstein, S. J. (1991). Protein Methods. $3^{\text {rd }}$ Edn., Wiley-liss, Inc., New York. pp. 230.

Budiarti, S. W., Widyastuti, S. M. and Margino, S. T.

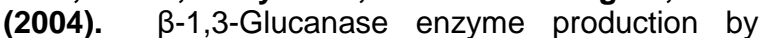
Tricoderma reesei during mycoparasitism. Makalah Seminar Pertemuan Bioteknologi Indonesia, Malang.

Cheba, B. A., Zaghloul T. I., EL-Mahdy, A. R. and ELMassry, M. H. (2016). Effect of $\mathrm{pH}$ and temperature on Bacillus sp. R2 chitinase activity and stability. Procedia Technology 22, 471-477.

Chen, H. L. and Juang, R. S. (2008). Recovery and separation of surfactin from pretreated fermentation both by physical and chemical extraction. Biochemical Engineering Journal 38(1), 39-46.

Chang, W. T., Chen, Y. C. and Jao, C. L. (2007). Antifungal activity and enhancement of plant growth by Bacillus cereus grown on shellfish chitin wastes. Bioresource Technology 98(6), 1224-1230.

Cota, I. E., Troncoso-Rojas, T., Sotelo-Mundo, S., Sanchez-Estrada, A. and Tiznado-Hernandez, M. E. (2006). Chitinase and 1,3-glucanase enzymatic activities in response to infection by Alternaria alternata evaluated in two stages of development in different tomato fruit varieties. Scientia Horticulturae 112(1), 42-50.
Darwiati, W. (2009). Uji efikasi ekstrak tanaman suren (Toona sinensis Meer) sebagai pestisida nabati dalam pengendalian hama daun (Eurema spp. dan Spodoptera litura F.). Thesis, Sekolah Pascasarjana IPB.

de la Vega, L. M., Barboza-Corona J. E., AguilarUscanga, M. G. and Ramirez-Lepe, M. (2006). Purification and characterization of an excochitinase from Bacillus thuringiensis subsp. aizawai and its action against phytopathogenic fungi. Canadian Journal of Microbiology 52(7), 651-657.

Dewi, R, T., Mubarik, N. R. and Suhartono M. T. (2017). Medium optimization of $\beta$-glucanase production by Bacillus subtilis SAHA 32.6 used as biological control of oil palm. Emirates Journal of Food and Agriculture 28(2), 116-125.

Farabee, M. J. (2001). Enzyme: Organic Catalyst. W.H. Freeman and Co., USA

Fardiaz, S. (1988). Fisiologi Fermentasi. Pusat Antar Universitas ITB, Bandung.

Fesel, H. P. and Zuccaro, A. (2016). $\beta$-glucan: Crucial component of the fungal cell wall and elusive MAMP in plants. Fungal Genetics and Biology 90, 53-60.

Fiddaman, P. J. and Rossall, S. (1993). The production of antifungal volatiles by Bacillus subtilis. Journal of Applied Bacteriology 74(2), 119-126.

Gesheva, V., Ivanova, V. and Gesheva R. (2005). Effects of nutrients on the production of AK-111-81 macrolide antibiotic by Streptomyces hygroscopicus. Microbiological Research 160(3), 243-248.

Gong, M., Wang, J. D., Zhang, J., Yang, H., Lu, X. F., Pei, Y. and Cheng, J. Q. (2006). Study of the antifungal ability of Bacillus subtilis PY-1 in vitro and identification of its antifungal substance (Iturin A). Acta Biochemica et Biophysica Sinica 38(4), 233-240.

Hogg, S. (2005). Essential microbiology. John Wiley \& Sons Ltd., UK.

Hushiarian, R., Yusof, N. A. and Dutse, S. W. (2013). Detection and control of Ganoderma boninense: Strategies and perspectives. Biomedical and Life Sciences 2(555), 1-12.

Islam, M. R., Jeong, Y. T., Lee Y. S. and Song, C. H. (2012). Isolation and identification of antifungal compounds from Bacillus subtilis C9 inhibiting the growth of plant pathogenic pungi. Mycobiology 40(1), 59-66.

Jholapara, R. J., Mehta, R. S. and Sawant, C. S. (2013). Optimization of cultural conditions for chitinase production from chitinolytic bacterium isolated from the soil sample. International Journal of Pharma and Bio Science 4(2), 464-471.

Karunya, S. K., Reetha, D., Saranraj, P. and Milton, D. J. (2011). Optimization and purification of chitinase produced by Bacillus subtilis and its antifungal activity against plant pathogens. International Journal of Pharmaceutical and Biological Archives 2(6), 16801685.

Kumar, A., Saini, P. and Shrivastava, J, N. (2009). Production of peptide antifungal antibiotic and 
biocontrol activity of Bacillus subtilis. Indian Journal of Experimental Biology 47(1), 57-62.

Kim, K. S. and Yun, H, S. (2006). Production of soluble $\beta$-glucan from the cell wall of Saccharomyces cerevisiae. Enzyme and Microbial Technology 39(3), 496-500.

Leelasuphakul, W., Hemmanee, P. and Chuenchitt, S. (2008). Growth inhibitory properties of Bacillus subtilis strains and their metabolites against the green mold pathogen (Penicillium digitatum Sacc.) of citrus fruit. Postharvest Biology and Technology 48(1), 113-121.

Lestari, P., Prihatiningsih, N. and Djatmiko, H. A. (2017). Partial biochemical characterization of crude extract extracellular chitinase enzyme from Bacillus subtilis B 298. IOP Conference Series: Materials Science and Engineering 172, 1-9.

Lenny, S. (2006). Isolasi dan Uji Bioaktifitas Kandungan Kimia Utama Puding Merah dengan Metoda Uji Brine Shrimp. Thesis. Universitas Sumatera Utara, Sumatera Utara, Indonesia.

Liu, D., Cai, J., Xie, C, C., Liu, C. and Chen, Y. H. (2010). Purification and partial characterization of a $36-\mathrm{kDa}$ chitinase from Bacillus thuringensis subsp. colmeri, and its biocontrol potential. Enzyme and Microbial Technology 46(3-4), 252-256.

Mardanova, A. M., Hadieva, G. F., Lutfullin, M. T., Khilyas, I. V., Minnullina, L. F., Gilyazeva, A. G., Bogomolnaya, L. M. and Sharipova, M. R. (2017). Bacillus subtilis strains with antifungal activity against the phytopathogenic fungi. Agricultural Sciences 8(1), 1-20.

Madigan, M. T., Martinko, J. M., Bender, K. S., Buckley, D. H. and Stahl, D. A. (2012). Brock Biology of Microorganisms. Pearson, San Francisco, CA. pp. 415-416.

Meena, V. S., Maurya, B. R., Meena, S. K., Meena, R. K., Kumar, A, Verma, J. P. and Singh, N. P. (2016). Can Bacillus species enhance nutrient availability in agricultural soils? In: Bacilli and Agrobiotechnology. Islam, M. T., Rahman, M., Pandey, P., Jha, C. K. and Aeron, A. (eds.). Springer International. pp. 367-395.

Natsir, H. (2014). Optimasi produksi dan karakterisasi sifat biokimiawi enzim glukanase dari $B$. licheniformis HSA3-1a asal sumber air panas Sulawesi Selatan. Artikel IImiah, Unhas Repository. pp. 1-9.

Nielsen, J, E., Borchert, T. V. and Vriend, G. (2001). The determinants of alpha-amylase pH-activity profiles. Protein Engineering, Design, and Selection, 14(7), 505-512.

Pal, K. K. and Gardener, B. M. (2006). Biological control of plant pathogens. The Plant Health Instructor 1-20.

Purkan, P., Baktir, A. and Sayyidan, A. R. (2016). Produksi enzim kitinase dari Aspergillus niger menggunakan limbah cangkang rajungan sebagai induser. Journal Kimia Riset 1(1), 34-41.

Pitson, S. M., Seviour, R. J. and McDougall, B, M. (1993). Noncellulolytic fungal $\beta$-glucanases: Their physiology and regulation. Enzyme and Microbial Technology 5(3), 178-192.
Ramyabharathi, S. A. and Raguchander T. (2014). Efficacy of secondary metabolites produced by Bacillus subtilis EPCO16 against tomato wilt pathogen Fusarium oxysporum f.sp. lycopersici. Journal of Mycology and Plant Pathology 44(2), 148-153.

Ridwan, Y., Darusman, L. K. and Satrija, E. H. (2005). Kandungan kimia berbagai ekstrak daun miana (Coleus blumei benth) dan efek anthelmintiknya terhadap cacing pita pada ayam. Journal IImu Pertanian Indonesia 11(2), 1-6.

Senol, M., Nadaroglu, H., Dikbas, N. and Kotan, R. (2014). Purification of chitinase enzymes from Bacillus subtilis bacteria TV-125, investigation of kinetic properties and antifungal activity against Fusarium culmorum. Annals of Clinical Microbiology and Antimicrobials 13(35), 1-7.

Stulke, J., Hanschke, R. and Hecker, M. (1993). Temporal activation of $\beta$-glucanase synthesis in Bacillus subtilis is mediated by the GTP pool. Journal of General Microbiology 139, 2041-2045.

Trotta, P. P., Vaira, P. W., Pinkus M. L. and Meister A. (1973). Observations on the $\mathrm{pH}$ dependence of the glutaminase activity of a glutamine amidotransferase, carbamylphosphate synthesis. Proceedings of the National Academy of the United States of America 70(10), 2717-2721.

Vidhyasekaran, P. (1997). Fungal pathogenesis in plants and crops: Molecular biology and host defense mechanism (2nd Edition) CRC Pres, Taylor and Francis Group LLC.

Wang, S. L. and Change, W. T. (1997). Purification and characterization of two bifunctional chitinase/ lysoenzyme extracellularly produced by Pseudomonas aeruginosa K-187 in a shrimp and crab shell power medium. Applied and Environmental Microbiology 63(2), 380-386.

Wijaya, S. P. (2015). Potensi antagonis bakteri endofit tanaman kelapa sawit (Elaeis guineensis Jacq.) terhadap fungi Ganoderma boninense Pat. Penerbit Program Studi Bioteknologi, Sekolah IImu Dan Teknologi Hayati, Institut Teknologi Bandung.

Wilson, K. and Walker, J. (2005). Principles and techniques of practical biochemistry. Wilson, K. and Walker, J. (eds.) Cambridge University Press, Cambridge. pp. 802-978.

Wrobel, A. B., Blazejak, S., Kawarska, A., Rozanska, L. S., Gientka, I. and Majewska, E. (2014). Evaluation of the efficiency of different disruption methods on yeast cell wall preparation for $\beta$-Glucan isolation. Molecules 19, 20941-20961.

Yurnaliza, Margino, S. and Sembiring, L. (2011). Kemampuan kitinase Streptomyces Rkt5 sebagai antijamur terhadap patogen Fusarium oxysporum. Jurnal Natur Indonesia 14(1), 42-46. 